\title{
RELASI AGAMA DAN SAINS DALAM STUDI ISLAM DI PTAI
}

\section{Rasmianto}

Fakultas Tarbiyah Universitas Islam Negeri (UIN) JI. Gajayana 50 Telp.0341-551354 Malang

\begin{abstract}
It cannot be denied that religion and science play important roles in human life. The development of science in this modern world does not automatically reduce the influence of religion in human life, as predicted by the secularization theory. The fact that religion and science tend to be firmer interests many people, especially concerning the relation between them. Many perspectives and religious doctrines that seem in contradiction with the theory of modern science may arouse a conflict between religion and science. The case of execution to Galileo by the church in the nineteenth century and the long debate between the supporters of the Evolution and those of the Theory of Creation are the real proofs of the conflict between religion and science. To avoid the conflict, many people have tried to find the most appropriate model of relation. In the contemporary era, the "new flow" discussion of religion and science emerges. The discussion not only focuses on the level of discourse but also implementation. Many studies of integrativeinterconnection between religion and science in Islamic tertiary educational institutions indicate the efforts to match religion with science.
\end{abstract}

Key words: religion, science, evolution

Ulul Albab, Vol. 9 No. 1, 2008 


\section{Pendahuluan}

Sebagaimana diketahui wacana tentang agama dewasa ini kembali menjadi menarik dan menjadi obyek kajian para filosof, sosiolog maupun teolog. Agama yang dalam perspektif positivisme disetarakan dengan 'mitos' dan karenanya sempat diramalkan akan terlibas oleh kekuatan 'ideologi' dan desakan 'sains-teknologi', kini justru menunjukkan kebangkitannya. Di berbagai belahan dunia, studi keagamaan malah semakin berkembang pesat bersamaan dengan ketika dunia modern semakin membutuhkan penjelasan yang bersifat ilmiah dari perilaku masyarakat dan kebudayaan mereka. Studi keagamaan telah menjadi tuntutan modernitas itu sendiri. Pada tahap selanjutnya, studi keagamaan diciptakan dari perpaduan studi-studi historis, ilmu perbandingan dan ilmu sosial yang berrpuncak pada filsafat. Dengan cepat studi keagamaan menghasilkan teori-teori agama melalui proyekproyek yang dijalankan di dunia akademik.

Dari berbagai studi keagamaan yang berkembang dewasa ini, setidaknya ada tiga wacana yang sering diperdebatkan yaitu agama, budaya dan sains. Permasalahan utamanya, barangkali lebih karena pada setiap era, bahkan di setiap peradaban, ketiga unsur di atas mempengaruhi proses terbentuknya masyarakat. Perkembangannya bahkan diyakini akan mempengaruhi arah masyarakat dunia masa depan, dengan metode kerja, intensitas dan sistem yang berbeda. Sayangnya, antara agama, budaya dan sains dalam perjalanan sejarahnya belum bisa diakurkan satu sama lain. Sejarah peradaban eropa telah mencatat suatu era di mana agama (Kristen) sedemikian mendominasi sehingga terjadi penaklukkan -tidak hanya penjinakanterhadap sains dan agama. Namun jauh sebelum itu terjadi, peradaban Yunani yang menjadi sumber inspirasi peradaban barat pada masa jayanya menjunjung tinggi sains melampaui agama dan budaya.

Tulisan ini merupakan refleksi atau catatan-catatan akademis penulis selama mengikuti perkuliahan Agama, Budaya Dan Sains yang diampu oleh Prof. Dr.H.Amin Abdullah. Tulisan ini tidak akan membahas hubungan ketiganya (agama, budaya dan sains) tetapi memfokuskan pada relasi agama dan sains serta kemungkinan pengajarannya di Perguruan Tinggi Agama 
Islam (PTAI) tetapi sebelum membahas ke arah itu akan dibahas relasi agama dan sains serta bagaimana pandangan masyarakat terhadap pola relasi tersebut.

\section{Pembahasan}

\section{Relasi Agama dan Sains}

Istilah religion berasal dari eropa yang diartikan sebagai " $a$ general cerm to embrace certain human interests antara lain the world over." Belakangan kata ini berevolusi setelah terjadi percampuran dengan persoalan entitas kemanusiaan dan non-kemanusiaan seperti the sacred, the supermatural, the self Existent, the Absolute, orang simply, 'God'. Dalam bahasa Inggris sendiri diartikan: "the belief in the existentence of a god orang gods." Adapun dalam "The Dicrionary of Belief", istilah "religion" di artikan "a system of beliefe about reality, exixtence, the universe, the supernatural or the devine and practices usually arising out of these beliefs (Rundell, 2002: 1194).

Proses peralihan makna religion dari kata kerja menjadi kata benda dimaknai sebagai himpunan doktrin, ajaran serta hukum-hukum yang telah baku yang diyakini sebagai kodifikasi perintah Tuhan untuk manusia (Hidayat, 1995: 91).

Selanjutnya, istilah agama sendiri berasal dari bahasa sanskerta. Ada pendapat yang menyatakan bahwa kata agama tersusun dari dua kata "a" berarti tidak, dan "gam" artinya pergi, tetap ditempat, diwarisi turun temurun. Menurut Harun Nasution, agama memang mempunyai sifat yang demikian. Ada lagi pendapat yang menyatakan bahwa agama berarti teks atau kitab suci. Dan agama-agama memang mempunyai kitab-kitab suci (Nasution, 1985: 9).

Adapun sains berasal dari kata "science" yang berarti (1) the study and knowledge or the physical word and its behaviour that Islam based on exeperience and proven facts and organized into a system (2) "a subject such as chemistry, physic, or bilogy," (3) "an organized way orang making, arranging, or dealing with something" (Rundell, 2002: 1268). 
Lebih lanjut Umar, A. Jenie dalam salah satu tulisannya, ketika mendefenisikan arti sains, mengutip pendapat Laffrey dan Rowe dan Morris. Menurut Laffrey dan Rowe, sains adalah "any systematic field of study or body of knowledge that aims, -through exeperiment, observation and deduction-, to produce reliable expalanation of phenomena with reference to the material or physical word." Adapun menurut Morris, sains adalah "the systernatic observation of natural events and conditions of order to discover facts about them and to formulate laws and principles based on these facts" (Jenie, 2002: 2).

Relasi sains dan agama telah menjadi topik yang cukup hangat dikalangan ilmuwan sejak beberapa abad yang lalu. Pada mulanya relasi sains dan agama merupakan wacana yang kontroversial di dunia barat. Akan tetapi kemajuan sains dan teknologi di dunia barat telah memberikan dampak yang cukup besar bagi masyarakat muslim. Akibatnya, kontroversi antara sains dan agama juga menjadi salah satu isu yang banyak dibicarakan di kalangan sarjana muslim. Karena, hingga kini masih kuat anggapan dalam masyarakat luas yang mengatakan bahwa "agama" dan "sains" adalah dua entitas yang tidak bisa dipertemukan. Keduanya mempunyai wilayah sendirisendiri terpisah antara satu dengan lainnya (Abdullah, 2006: 92).

Pertanyaan-pertanyaan yang sering dimunculkan dalam konteks relasi ini adalah: Apakah sains telah menyebabkan agama tidak masuk akal lagi secara intelektual? Apakah sains itu menyingkirkan adanya Tuhan yang personal? Bukankah evolusi menyebabkan seluruh ide mengenai penyelenggaraan ilahi tidak masuk akal lagi? Dan, bukankah biologi modern sudah memperlihatkan bahwa hidup dan akal-budi dapat dijelaskan oleh ilmu kimia dengan akibat bahwa gagasan-gagasan mengenai jiwa dan ruh pun hanyalah semu belaka? Apakah kita masih harus percaya bahwa dunia ini diciptakan Tuhan? Atau, bahwa kita berada di sini karena memang benarbenar dikehendaki oleh sesuatu atau seseorang? Apakah tidak mungkin bahwa semua pola yang rumit dalam alam ini hanyalah hasil dari suatu peluang yang serba kebetulan? Dalam zaman yang ditandai dengan kemajuan sains ini, dapatkah kita secara jujur percaya bahwa alam semesta ini memang mempunyai arah atau tujuan tertentu? 
Pertanyaan-pertanyaan ini merupakan "masalah sains" dan agama. Bagi agama, keberhasilan gilang gemilang sains diberbagai aspek kehidupan manusia, terutama sejak zaman renaisans, sekurang-kurangnya menimbulkan tanggapan yang ambigu: harapan baru dan juga kekhawatiran baru.

Agama mungkin bisa mengharapkan sains membersihkan unsur-unsur takhayyul dan mitos yang menyusup, disadari atau tidak, ke dalam ajaranajarannya. Tetapi agama juga khawatir kalau-kalau sains akan meninggalkannya atau malah meniadakannya. Meskipun harapan ini tampaknya tidak sepenuhnya terpenuhi, kecemasannya pun untung tidak terlalu mengkhawatirkan.

Pada realitasnya, agama menjalin hubungan dengan sains dalam pola yang tidak sederhana. Ada spektrum yang cukup luas dalam pandangan tentang relasi agama-sains: dari ekstrim konflik hingga peleburan total. Dalam wacana kontemporer terdapat empat teori yang diangkat ke panggung perdebatan relasi agama-sains; konflik, kontras (independen), kontak (dialog) dan konfirmasi (integrasi).

Kubu konfliks memandang agama dan sains secara instrinsik berlawanan. Keduanya bertarung untuk saling menyalahkan, bahkan saling meniadakan, dan karena itu tidak mungkin bisa dipertemukan. Seseorang tidak bisa secara bersamaan mendukung teori sains dan keyakinan agama. Agama tidak dapat membuktikan kepercayaan dan pandangannya secara jelas (straight forward), sementara sains bisa. Sementara itu kaum agamawan berargumen sebaliknya, baginya sains tidak punya otoritas untuk menjelaskan segala hal yang ada dimuka bumi. Rasio yang dimiliki oleh manusia sebagai satu-satunya instrumen sains sangatlah terbatas dan dibatasi. Maka, untuk menjelaskan segala fenomena dan misteri dunia hanya bisa dipaparkan oleh agama. Model konfrontasi ini dalam pandangan Barbour diwakili oleh biblical literalism dan kelompok scientific matererialism. Biblical literalism berkeyakinan bahwa kitab suci berlaku universal, valid, final dan memberikan data kebenaran yang tak tebantahkan. Sementara scientific materialialism berpendirian bahwa metode ilmiah adalah satu-satunya cara yang tepat untuk 
mendapatkan pengetahuan. Golongan ini hanya mempercayai realitas yang nyata dan bisa dibuktikan secara material (Haught, 2005: 2-6).

Lebih lunak dari itu, kubu kontras (independen) memandang agama dan sains masing-masing memiliki persoalan, wilayah kerja, metode sendirisendiri yang otonom, terpisah dan absah. Meskipun tidak perlu bertemu (contact), keduanya harus saling menghormati integritas masing-masing. Model pemisahan ini disamping didasari oleh keinginan untuk menghindari konflik antara agama dan sains, adalah juga sebagai konsekuensi dari munculnya ilmu pengetahuan baru (new knowledge) seperti penjelasan biologis atau organisme organ.

Langdan Gilhey sebagaimana dikutip Barbour memberikan perbedaan mendasar antara agama dan sains. 1) Sains menjelaskan data obyektif umum dan berulang-ulang, sementara agamabercakap tentang eksistensi tatanan dan keindahan dunia. 2) Sains mengajukan pertanyaan "bagaimana" yang obyektif, sementara agama mengajukan pertanyaan "mengapa" tentang makna dan tujuan serta asal mula dan takdir terakhir. 3) Basis otoritas dalam sains adalah koherensi logis dan kesesuaian ekperimental, sementara otoritas dalam agama adalah Tuhan atau wahyu. 4) Sains melakukan prediksi kuantitatif yang dapat diuji secara eksperimental, sementara agama harus menggunakan bahasa simbolis dan analogis karena Tuhan bersifat transenden (Haught, 2005: 9).

Model seperti ini sebenarnya lahir untuk mengakhiri pertentangan sains dan agama. Akan tetapi sesungguhnya akan mempertajam pertentangan antar keduanya. Sebab kondisinya berjalan tanpa ada dialog dan kerjasama. Maka jalan alternatif adalah dialog.

Alih-alih menghindari pertemuan, kubu kontak/dialog menyarankan agama salingbertukar pandangandengan sains untuk memperkaya perspektif tentang realitas. Akan tetapi keduanya tidak mesti bermufakat, apalagi meleburkan diri. Berbeda dengan model independen yang meng-edepankan perbedaan, model dialog ini justru mencari titik persamaan antara sains dan agama. Kesamaan antara sains dan agama menurut Barbour bisa terjadi 
pada kesamaan metodologis dan konsep. Secara metodologis kebenaran sains tidak selamanya obyektif sebagaimana agama tidak selamanya subyektif. Sementara secara konseptual keduanya menemukan muara persamaan, misalnya pada teori komunikasi informasi (communication of information) (Haught, 2005: 78-82).

Bergerak lebih dari itu, kubu konfirmasi/integrasi menyarankan agama dan sains agar saling mengukuhkan, terutama dalam berbagai pandangan tentang anggapan dasar tentang realitas, tanpa harus kehilangan identitas masing-masing (Haught, 2005: 40-42). Model ini adalah paling ideal dalam hubungan agama dan sains. Pada model ini posisi sains, dalam bahasa Haught adalah untuk memberikan konfirmasi (baik yang memperkuat atau mendukung) keyakinan tentang Tuhan sebagai pencipta alam semesta (Haught, 2005: 24).

Secara sepintas, unifikasi dan konfirmasi antara sains modern dengan dogma agama-agama nampaknya tidak mungkin dilakukan mengingat kedua domain tersebut berbeda secara diametral. Dari sudut pandang ontologis, sains memandang realitas sebagai sesuatu yang bersifat empiris, kalkulatif, dan verifikatif. Sementara itu agama memandang realitas sebagai sesuatu yang bersifat metafisis, intuitif dan spekulatif. Mempertemukan dua sudut pandang di dalam suatu kajian ilmiah berarti sekaligus memposisikan realitas konkrit dan abstrak pada satu wilayah yang sama.

Sementara dari sudut pandang epistemologis, konvergensi antara sains dan agama juga mengalami kendala yang cukup besar. Paradigma sains yang bersifat positivistik, empiris dan rasional tentu saja tidak sesuai dengan paradigma agama yang bersifat spiritual, metafisis, dan moral. Meskipun berbeda paradigma, namun sebagian kalangan ada yang menilai bahwa doktrin agama yang bersumber dari wahyu jauh lebih tinggi posisinya dibandingkan dengan ilmu pengetahuan yang bersumber dari akal dan rasio manusia. Asumsi ini kemudian memberikan kekuatan-kekuatan bagi agama untuk selalu mengontrol pencapaian-pencapaian dalam bidang sains dan teknologi. Penemuan-penemuan sains dan teknologi yang dianggap 
bertentangan dengan doktrin agama harus dihentikan agar tidak merusak nilai-nilai kesakralan agama yang benar secara taken for granted.

Penyalahgunaan otoritas agama untuk mengontrol laju perkembangan sains dan teknologi dapat berdampak buruk. Wajah buram relasi sains dan agama di abad pertengahan yang lalu masih selalu membayang-bayangi masyarakat ilmuwan kontemporer. Penggunaan kuasa kontrol yang terlalu berlebihan dari pihak agama dapat menyebabkan agama akan ditinggalkan oleh para penganutnya. Sebaliknya, pengembangan sains dan teknologi yang tidak menghiraukan doktrin-doktrin agama dapat menimbulkan krisis spiritual dikalangan para ilmuan. Pada terminal inilah kita melihat adanya persinggungan akrab antara sains dan agama. Ada dua kesimpulan yang bisa ditarik dalam relasi sains dan agama yaitu:

1. Perkiraan metafisis dalam sains dan teknologi seringkali didasarkan pada pandangan agama.

2. Pandangan agama sangat efektif dalam memberikan orientasi terhadap penerapan sains dan teknologi (Sugiharto, 2005: 39-52).

Untuk memperkuat kesimpulan ini perlu mengambil pelajaran pada usaha dan semangat Rolston yang ingin mendialogkan antara sains dan agama. Sejak awal Rolston telah menegaskan semangatnya mengkaji sains guna menemukan ruang apakah yang ditinggalkannya untuk agama. Semangat ini didasarkan pada pengetahuan dan keyakinannya bahwa sains dalam berbagai manifestasinya, seperti yang sekarang kita kenal menunjukkan adanya ketidaksempurnaan dalam menjawab pertanyaan-pertanyaan akhir. Dan disitulah, menurut Rolston, interpretasiagama diperlukan sebagai penyempurna keterbatasan penjelasan sains.

Cara yang digunakan Rolston adalah dengan mengambil isu-isu representativ sains dan kemudian mengintegrasikannya dalam sebuah survey yang ia mulai dari matter, lalu bergerak melalui life, mind, culture, history dan spirit. Urut-urutan pembahasan ini menunjukkan kemajuan logis serta 
memberikan kisah perkembangan dalam dunia, tempat sains dan agama mencoba memberi penilaian. Alam semesta yang dikisahkan dalam sejarah dunia serta peran kita di dalam dunia drama tersebut, memunculkan pertanyaan yang bersifat keagamaan. Bagi Rolstons penggabungan kedua wilayah ini (sains dan agama) merupakan proses historis yang akan berujung pada pendekatan integratif (Rolston, 1987: 298).

\section{Sains Moderen dan Islam}

Setelah membahas relasi sains dan agama secara umum di atas, lalu pertanyaan yang akan dikemukakan adalah: Bagaimana sains dalam Islam? Islam mempersilahkan kepada kecerdasan-kecerdasan manusia untuk mengembangkan sains dan teknologi, bukankah wahyu yang pertama kali diturunkan adalah isyarat yang paling nyata bahwa Islam sangat apresiatif terhadap sains?. Menurut Mahdi Ghulsyani bahwa dalam al-Qur'an terdapat kurang lebih 750 ayat yang mempunyai relevansi dengan sains dan teknologi (Ghulsyani, 1998: 39).

Karena itu, dalam Islam sendiri, para ilmuwan tidak menemukan kesulitan untuk menghubungkan alam ini (sains) dan Tuhan, selain disebabkan oleh adanya al-Qur'an, para ilmuwan juga sering menganggap bahwa poros utama ilmu pengetahuan modem juga tidak sedikit yang diwariskan oleh Islam (Pusposutarjo, 1996: 29-44).

Keinginan atau obsesi akan bangkitnya kembali peradaban Islam secara jujur lahir dari bentuk romantisisme terhadap sejarah masa lampau. Walau begitu, keinginan itu tentunya sesuatu yang wajar. Bahkan menjadi kewajiban setiap muslim untuk dapat membangun suatu peradaban yang berlandaskan nilai-nilai Islam. Karena itu, catatan sejarah di atas akan membuat kita lebih bijak dalam melihat ke arah mana kita akan menuju. Satu hal yang jelas adalah sebuah peradaban baru dapat berdiri kokoh jika berhasil membangun suatu sistem pengetahuan yang mapan. Bangkitnya peradaban Islam akan sangat tergantung pada keberhasilan dalam bidang sains melalui prestasi institusional dan epistemologis menuju pada proses dekonstruksi epistemologi sains moderen yang memungkinkan nilai-nilai

Ulul Albab, Vol. 9 No. 1, 2008 
Islam terserap secara seimbang ke dalam sistem pengetahuan yang dibangun tanpa harus menjadikan sains sebagai alat legitimasi agama dan sebaliknya. Ini sejalan dengan gagasan islamisasi pengetahuan yang pernah dilontarkan oleh Alatas atau Ismail Raji al-faruqi.

Mengapa masyarakat Islam perlu melakukan reformasi sains moderen? Bukankah sains moderen telah begitu banyak memberikan manfaat bagi manusia? Pernyataan ini mungkin benar jika kita melihat tanpa sikap kritis bagaimana sains moderen membuat kehidupan (sekelompok) manusia menjadi lebih sejahtera. Argumen yang masuk akal datang dari Sal Restivo yang mengungkap bagaimana sains moderen adalah sebuah masalah sosial karena lahir dari sistem masyarakat moderen yang cacat. Secara historispun kita bisa memahami bagaimana sains moderen lahir sebagai mesin eksploitasi sistem kapitalisme. Paul Feyerabend bahkan mengkritik sains moderen sebagai ancaman terhadap nilai-nilai demokrasi, kualitas hidup manusia, dan bahkan kelangsungan hidup bumi beserta isinya. Dalam kondisisi seperti ini, Islam semestinya dapat menjadi suatu alternatif dalam mengembangkan sains ke arah yang lebih bijak.

Walau begitu, islamisasi pengetahuan adalah sebuah proyek ambisius untuk tidak menyebutnya utopia. Proyek islamisasi pengetahuan yang sarat dengan nilai akan sangat sulit tercapai karena bertentangan dengan dogma sains moderen yang mengklaim dirinya sebagai "bebas" nilai sehingga bersifat netral dan universal. Klaim netralitas dan universalitas sains moderen itu sendiri pada dasarnya bermasalah. Netralitas justru menjadi tempat perlindungan bagi sains moderen dari kritik terhadap berbagai permasalahan sosial yang diproduksinya. Sementara universalitas tidak lebih dari sekedar alat hegemoni sains moderen terhadap sistem pengetahuan yang lain. Studi sosial dan kultural terhadap sains moderen yang dilakukan beberapa sarjana memberi cukup bukti bahwa sains dan pengetahuan yang dihasilkannya selalu bersifat kultural, terkonstruksi secara sosial, dan tidak pernah lepas dari kepentingan ekonomi dan politik. Inilah tantangan terbesar bagi saintis muslim dalam upaya membangun sistem pengetahuan yang Islami. 


\section{Studi Agama dan Sains Di PTAI}

\section{a. Studi Islam di PTAI: Studi Keagamaan atau Studi Ilmiah?}

Salah satu dilema yang dihadapi PTAI adalah ketegangan antara tuntutan yang diarahkan kepadanya sebagai lembaga yang menawarkan studi keagamaan disatu pihak dan studi ilmiah di pihak lain. Dalam studi keagamaan, PTAI dituntut untuk mengajarkan agama sebagai kebenaran yang diterima apa adanya (taken for granted) untuk kemudian ditransfer atau didakwahkan kepada masyarakat. Watak studi keagamaan adalah normatif yakni, mengkaji "apa yang seharusnya" menurut agama. Kadang-kadang, ia juga berwatak apologetik, yaitu membela kebenaran agama sendiri dengan menunjukkan "kekurangan" agama lain, atau membela aliran tertentu dalam rangka menjatuhkan aliran lain yang dianggap telah menyimpang dari "kebenaran." Kelebihan dari studi keagamaan ini adalah bahwa ia dapat memberikan kepastian atau pegangan bagi mereka yang ingin menjalankan ajaran agama dalam kehidupan sehari-hari.

Tetapi, jika PTAI hanya berfungsi sebagai lembaga yang menyajikan agama sebagai sesuatu yang "siap pakai" untuk kemudian ditransfer ke masyarakat, lalu apa bedanya PTAI dengan Majlis Ta'lim atau Pondok Pesantren yang juga melaksanakan fungsi yang sama? Disinilah kemudian PTAI perlu menampilkan dirinya sebagai perguruan tinggi, sebuah lembaga ilmiah yang mempelajari agama dengan pendekatan ilmiah, yakni pendekatan yang bersifat rasional, empiris, kritis dan terbuka. Semua aliran dan mazhab akan dipelajari secara historis-empiris dan dianalisis secara rasional tanpa keharusan memihak salah satu dari aliran-aliran tersebut. Tugas seorang ilmuan adalah menyajikan Islam bukan sebagai kebenaran transenden yang taken for granted, melainkan Islam yang ada dalam kenyataan, Islam dalam sejarah manusia, baik sejarah pemikiran ataupun sejarah sosial. Ketika seorang ilmuan mengkaji sebuah karya ulama tertentu, maka kajian itu bukanlah dalam rangka mencari "pegangan" seperti yang dilakukan oleh studi keagamaan, melainkan dalam rangka memahami "isi" kitab tersebut dan menganalsisnya dalam koteks sosial dimana kitab itu ditulis. 
Dengan demikian, studi keagamaan dan studi ilmiah memang berbeda dan kadang-kadang menimbulkan ketegangan. Ketegangan ini bisa diilustrasikan dengan pertanyaan seorang mahasiswa setelah ia memperhatikan penjelasan dosennya bahwa argumen-argumen al-Ghazali yang menolak bahkan mengkafirkan beberapa pendapat Ibnu Sina disatu pihak dan argumen-argumen Ibnu Rusyd yang membela Ibnu Sina di pihak lain nampaknya sama-sama kuat. Sang mahasiswa lantas bertanya: "lalu mana yang kita pegangi?" Pertanyaan itu muncul karena, bagi sang penanya, dalam perdebatan antara Ghazali dan Ibnu Rusyd itu mestinya sang dosen tidak hanya menyajikan argumen-argumen dari kedua belah pihak, melainkan juga keputusan tentang siapa yang paling kuat diantara keduanya untuk dijadikan pegangan. Selain itu, pertanyaan tersebut juga menunjukkan bahwa kita terbiasa dengan pola keagamaan yang monolitik sehingga kurang memiliki keberanian untuk menentukan pilihan ketika berhadapan dengan berbagai alternatif pendapat. Ketegangan ini mungkin juga dapat dilihat pada kiprah dosen PTAI yang disatu pihak merupakan insan akademis yang dituntut berfikir dan mengembangkan Islam dalam koridor ilmiah, tapi disisi lain, masyarakat menuntutnya untuk memberikan bimbingan dan nasehatnasehat agama yang berwatak normatif dan umumnya monolitik. Disatu pihak ia dituntutuntuk meneliti dan menulis karya-karya akademis, tapi di pihak lain, masyarakat meminta dirinya untuk mengisi ceramah dan pengajian dimana-mana, yang meskipun tidak bertentangan dengan profesi akademisnya, tapi mau tidak mau akan menyita waktu dan kesempatan baginya untuk lebih mengembangkan studi Islam dalam kerangka akademisilmiah tadi.

Memang tidak mudah untuk menjembatani dua hal ini. Kadangkadang penekanan pada sisi yang satu justeru mengorbankan sisi yang lain. Yang ideal tentu adalah sintesis antara keduanya. PTAI diharapkan dapat menyajikan kajian-kajian agama yang berwatak ilmiah sekaligus dapat menawarkan pemikiran-pemikiran segar atas dasar hasil-hasil telaah ilmiah itu yang dapat dijadikan 'pegangan' bagi masyarakat. Tentu 'pegangan' disini bukan dalam arti dogmatis, melainkan satu tawaran yang terbuka untuk 
dikritik dan menghargai tawaran-tawaran lain yang berbeda. Dengan demikian PTAI tidak akan terjurumus menjadi menara gading yang hanya menyajikan Islam dalam kerangka ilmiah tanpa memperhatikan relavansinya bagi kaum Muslim seperti yang dilakukan oleh sebagian Orientalis dan tidak juga jatuh pada sekadar upaya mereproduksi apa yang telah direkam dalam kitab-kitab klasik karya para ulama masa lalu sebagaimana yang dilakukan oleh pondok pesantren melainkan berusaha untuk menawarkan pemikiran-pemikiran keislaman yang segar dan sesuai dengan kebutuhan kekinian untuk mendorong transformasi sosial ke arah yang dicita-citakan Islam. Dengan ungkapan lain, pemikiran-pemikiran para ulama masa lalu tetap harus dipelajari dan diapresiasi, namun tidak harus berhenti sampai disitu saja, melainkan ditingkatkan dengan analisis mengenai problemproblem kekinian yang dihadapi oleh kaum Muslim untuk kemudian dicarikan alternatif pemecahannya.

\section{b. Kearah Integrasi Sains dan Agama Dalam Studi PTAI}

Sebagaimana diketahui, bidang ilmu yang dikembangkan di Perguruan Tinggi Agama Islam (PTAI) yaitu ulumuddin (usuluddin, syari'ah, tarbiyah, adab dan dakwah). Padahal, menurut Ibn Khaldun, ilmu dibagi menjadi dua yaitu ilmu naqliyah, ilmu berdasarkan wahyu dan ilmu aqliyah, ilmu yang berdasarkan logika. Berdasarkan klasifikasi ilmu semacam ini menjadi jelas bahwa sebetulnya perkembangan ilmu berjalan sedemikian luas.

Perkembangan budaya dan berbagai disiplin ilmu dewasa ini membuat segala bidang menjadi terintegrasi. Batas-batas antara satu disiplin ilmu dengan disiplin ilmu lainnya termasuk ilmu agama menjadi transparan. Kita tidak perlu mempermasalahkan ilmu agama dan non-agama, namun bagaimana ilmu tersebut dapat dimanfaatkan untuyk mencapai suatu tujuan. Hal ini pula yang memunculkan paradigma baru yang melihat bahwa pembidangan keilmuan selayaknya dikembangkan dalam lingkup yang lebih luas.

Ulul Albab, Vol. 9 No. 1, 2008 
Pengembangan berbagai disiplin ilmu seperti sains dan teknologi, kedokteran, astronomi, sosiologi, filsafat dan sebagainya di lingkungan PTAI adalah langkah maju untuk pencerahan dunia pendidikan Islam. Gagasan perubahan Institut Agama Islam Negeri (IAIN) menjadi Universitas Islam Negeri (UIN) untuk mengembangkan berbagai disiplin ilmu bertujuan antara lain menjembatani dikotomi berkepanjangan ilmu agama dan nonagama, menghilangkan keterasingan ilmu agama dari realitas kemodernan dan mengembalikan ilmu agama sebagai sumber ilmu pengetahuan.

Sebagaimanadiketahui bahwa ilmu pengetahuan berkembang seiring dengan keberadaan manusia. Dalam agama Islam, kita yakini bahwa ilmu agama (naqliyah) merupakan sumber dari ilmu pengetahuan lain karena ilmu agama bersifat mutlak. Ilmu agama bersifat normatif tekstual dan teological klasik yang meyakini kebenaran sebagai kebenaran Tuhan dan tidak perlu diragukan lagi.

Berbeda dengan sains, merupakan ilmu berdasarkan fakta, logika dan mendasarkan perkembangannya kepada apa yang dilihat, diukur dan dapat dibuktikan. Sains.bersifat positivis, empiris dan rasional. Sains berpijak pada rasio manusia pada saat itu sehingga kebenarannya bersifat relativ. Baik ilmu agama maupun sains berkembang mempunyai tujuan sama yaitu meningkatkan harkat dan martabat manusia.

Pendidikan modern memang mengembangkan disiplin ilmu dengan spesialisasi secara ketat, sehingga keterpaduan dian ara ilmu yang satu dengan yang lainnya menjadi hilang, dan melahirkan dikotomi kelompok ilmuilmu agama di satu pihak dan kelompok sains di pihak yang lain. Dikotomi itu berimplikasi pada terbentuknya perbedaan sikap di kalangan umat Islam secara tajam terhadap kedua kelompok ilmu tersebut. Ilmu-ilmu agama disikapi dan diperlakukan sebagai ilmu Allah swt yang bersifat sakral dan wajib untuk dipelajari. Sebaliknya, kelompok ilmu-ilmu sains (kealaman dan sosial) disikapi dan diperlakukan sebagai ilmu manusia yang bersifat profan dan tidak wajib untuk dipelajari. Akibatnya, terjadi reduksi ilmu agama dan dalam waktu yang sama juga terjadi pendangkalan ilmu pengetahuan. Situasi seperti ini membawa dampak pada ilmu-ilmu agama menjadi 
tidak menarik karena terlepas dari kehidupan nyata, sementara sains berkembangan tanpa sentuhan etika dan spiritualitas agama, sehingga disamping kehilangan makna juga bersifat destruktif.

PTAI harus mengembangkan pendidikan yang berperspektif Qur'ani, yakni pendidikan yang utuh menyentuh seluruh domain yang disebut Allah swt dalam kitab suci tersebut secara sistemik yang dikembangkan melalui konsep iman, ilmu dan amal dalam satu tarikan nafas dengan rajutan atau anyaman yang terhubungkan antara yang satu dan lainnya secara integratif.

Pengembangan kualitas PTAI dengan mengintegrasikan antara sains dan agama adalah dalam kerangka meningkatkan kualitas SDM (umat Islam) termasuk di Indonesia. Kenyataan bahwa Indonesia adalah negara dengan penduduk beragama Islam terbesar di dunia selalu dikaitkan dengan harapan akan bangkitnya Islam di negara ini. Fakta kuantitatif ini sayangnya belum cukup bagi kita untuk bersikap opnimis. Kendala besar bagi cita-cita tersebut ada pada dua sisi. Sisi pertama adalah masih lemahnya tradisi ilmiah di Indonesia. Walaupun Indonesia memiliki perguruan tinggi yang cukup berkualitas, kegiatan ilmiah yang sehat, khususnya dalam bidang sains, dalam menghasilkan pengetahuan yang orisinil masih jauh dari harapan. Kondisi ini menjadi lebih lemah lagi karena terpisahnya sains dan filsafat dalam wacana akademik. Masuknya sains dalam kategori ilmu eksakta sementara filsafat sebagai ilmu non-eksakta adalah indikasinya. Padahal kategori eksakta dan non-eksakta tersebut bersifat ilusif. Ini menyebabkan tidak terbentuknya suatu tradisi filsafat kritik sains yang mapan, dan sebaliknya, sains berjalan sendiri seolah-olah dia bersifat otonom.

Pada sisi kedua, merujuk pada tesis Nurcholish Majid, satu kenyataan bahwa masyarakat Islam di Indonesia tidak mewarisi tradisi intelektual peradaban Islam ketika masa keemasan. Islam muncul di Indonesia justru ketika tradisi intelektual Islam sedang mengalami penurunan di tempat asalnya sehingga tradisi intelektual tersebut tidak sempat terserap dalam sistem sosial dan kebudayaan. Disamping itu, salah satu syarat tumbuhnya tradisi intelektual adalah adanya sikap keterbukaan atau inklusivitas karena 
suatu sistem pengetahuan baru dapat terbentuk dengan baik jika berada dalam sistem sosial yang menghargai perbedaan dan keberagaman pemikiran. Hal ini menjadi isu penting mengingat masih kuatnya eksklusivitas di berbagai lapisan masyarakat Islam di Indonesia (Majid, 1992: 57).

Lalu apa yang harus dilakukan para pengelola PTAI dalam mengintegrasikan sains dan agama?. Era globalisasi menuntut institusi pendidikan termasuk PTAI. mampu bersaing secara sehat di antara lembaga sejenis. Karena itu perlunya suatu lembaga pendidikan menerapkan "mekanisme alokasi posisional". PTAI (STAIN, IAIN, UIN, PTAIS) yang biasanya membuka jurusan agama sudah waktunya memulai menyelenggarakan jurusan-jurusan lain atau umum seperti sains, ekonomi, maupun perbankan.

Pembukaan jurusan-jurusan umum atau sains di PTAI harus diiringi dengan penataan ulang praktik pendidikan Islam di PTAI. Sebagaimana kita ketahuui bila kita melihat praktek pendidikan Islam yang ada di Indonesia akan nampak beberapa hal. Pertama, pendidikan hanya menekankan pada kemampuan nalar. Pendidikan seharusnya lebih dari sekedar transfer of knowledge, tapi juga transfer of technology dan transfer of value. Kedua, masih kuatnya pemisahan atau dikotomi antara ilmu-ilmu umum dan ilmu-ilmu agama. Hal ini sudah lama disadari oleh banyak kalangan pendidikan dan pemikir pendidikan Islam, tapi untuk mengintegrasikan ilmu-ilmu tersebut bukan berarti tanpa halangan. Seharusnya ilmu-ilmu tersebut harus saling melengkapi demi tujuan kesejahteraan manusia di muka bumi. Padahal, sebagaimana diketahui bahwa dalam kehidupan senyatanya umat manusia, keduanya tidak dapat dipisahkan sama sekali. Pergerakan, kemajuan, kemunduran dan temuan-temuan dalam sains akan berpengaruh dalam kehidupan beragama dan begitu juga agama-agama yang tidak bersenrtuhan dengan sains (termasuk ilmu-ilmu sosial dan humaniora) juga akan kehilangan nuansa, daya pikat, daya tarik dan relevansinya dengan kehidupan nyata. Keduanya saling terhubung, terinkoneksi sedemikian rupa. Jembatan hanya mencerminkan sisa-sisa ketegangan masa lalu. Dalam era sekarang ini, dikotomi yang rigid seperti itu tidak menolong dan tidak mendidik. Perlu dirumuskan dan dipikirkan ulang bahwa di dalam yang 
transenden, ada juga unsur immanentnya disitu dan begitu sebaliknya. Dalam setiap apa yang dianggap "religius", sekaligus lengket di situ sisi "sekulernya" dan setiap yang diklaim sebagai wilayah "sains", juga ada "reli-giositas"nya, serta begitu sebaliknya (Abdullah, 2004: 7).

Hal lain yang perlu diperhatikan adalah kurikulum. Kurikulum yang akan diterapkan di PTAI harus menggunakan pendekatan integratif interkonektif yaitu pendekatan yang menempatkan wilayah agama dan sains, serta antar ilmu saling menyapa satu dengan yang lainnya sehingga menjadi satu bangunan utuh. Tidak ada dikotomi sains dan agama. Begitu juga tidal ada dikotomi antara ilmu-ilmu qauliyah/hadarah al-nash (ilmu-ilmu yang berkaitan dengan teks keagamaan) dengan ilmu-ilmu kauniyah ijtima'iyyah/ hadarah al-ilm (ilmu-ilmu kealamana dan kemasyarakatan) maupun hadarah al-falsafah (ilmu-ilmu etika kefilsafatan). Wilayah keilmuan tersebut tidak dikaji secara parsial melainkan dikaji secara integratif dan interkonektif atau saling berhubungan satu dengan lainnya.

Ada berbagai peluang ke arah interaksi sehat antara ilmu dan agama dalam kurikulum PTAI. Peluang-peluang itu ada misalnya terutama dalam mata kuliah umum (MKU), kegiatan kokurikuler atau ekstrakurikuler. Dalam konteks ini, beberapa mata kuliah penting yang bisa menjadi MKU adalah fenomenologi agama, etika, logika, estetika, multikulturalisme dan filsafat.

Analisis Rolston, Ian G.Barbour dan John. F. Haught tentang upaya pengembangan dialog maupun integrasi antara agama dan sains, dapat memperkaya dan menjadi bahan studi perbandingan terhadap teori seperti Ismalization of knowledge ala Faruqian dan Naquibian, scientification of Islam model Fazlurrahman, Spirituality of Science tawaran S.H. Nasr. Tawaran mereka sudah sepantasnya menjadi kurikulum atau bahan ajar di PTAI dalam melengkapi kajian sains dengan berpendekatan integratif interkoneksitas. Seperti dalam karya Rolston, dalam mendialogkan antara sains dan agama, pendekatan Rolston berujung pada integratif. Hal ini dapat pada bagian terakhir dari tesisnya Rolston, Nature, History and God. Hanya saja pada bab-bab sebelumnya tesisnya lebih banyak menyelami kewilayah 
sains, maka di bagian akhir, Rolston tampak banyak memperhatikan aspek teologis yang merupakan wilayah agama.

\section{Simpulan}

Sains dan agama memang memiliki perbedaan metodologis dan perbedaan klaim sehingga ungkapan formula serta karakter yang muncul juga berbeda. Pesan agama cenderung mengajak orang untuik return, yaitu menengok dan kembali ke belakang kepada Tuhan, sementara sains cenderung research yaitu melangkah ke depan dan menatap alam sebagai yang berada di depan dan selalu mengajak untuk difahami. Oleh karena itu, ketika sains dilihat dan diyakini sebagai ideologi kartena sebagian masyarakat merasa cukup menyelesaikan problem kehidupan melalui jasa sains, maka pada saat itu sains telah berdiri sejajar sebagai rival agama. Akan tetapi jika sains dipandang sebagai fasilitator teknis dan metode penafsiran terhadap alam raya, masa sains dapat diposisikan sebagai salah satu medium dan ekspresi agama.

Integrasi sains dan agama dapat dilakukan dengan mengambil inti filosofis ilmu-ilmu keagamaan fundamental Islam sebagaui paradigma sains masadepan. Inti filosofis itu adalah adanya hierarki epistemologis, aksiologis, kosmologis, dan teologis yang berkesesuaian dengan hierarki integralisme: materi, energi, informasi, nilai-nilai dan sumber. Proses integrasi ini dapat dianggap sebagai bagian dari proses Islamisasi peradaban masa depan. Dengan demikian, jika dapat melakukan hal ini, ia dapat menjadi simpul dalam jala-jala kebangkitan peradaban Islam di masa depan, menerima kembali sains sebagai si anak hilang untuk dikembangkan ke arah islami yang lebih konstruktif, produktif dan harmonis bersaing dengan universitas-universitas umum untuk menjadi center of exellence.

Sebagai penutup, apa yang diuraikan di atas adalah suatu bentuk kepedulian terhadap Islam dan sains di Indonesia yang patut mendapat perhatian publik secara terus menerus untuk membangkitan semangat dan tradisi kritik sains sekaligus kritik bagi masyarakat Islam di Indonesia. Dan karenanya studi relasi antar sains dan Islam seharusnya menjadi agenda penting, baik

Ulul Albab, Vol. 9 No. 1, 2008 
dalam tradisi filsafat Islam maupun dalam wacana sains di level teoritis maupun praksis.

\section{Daftar Pustaka}

Abdulrahim, Muhammad Imaduddin. 1996. Sains dalam Perspektif alQur'an, dalam Ahmad Syafi'ilmu Maarif \& Said tuhuleley (Penyunting), Al-Qur'an Dan Tantangan Modernitas. Yogyakarta: SIPRESS.

Abdullah, M.Amin. 2006. Islamic Studies di Perguruan Tinggi, Pendekatran Integratif Interkonektif. Yogyakarta: Pustaka Pelajar.

Barbour, Ian G. 2004. Juru Bicara Tuhan: Antara Sains dan Agama. Terjemahan oleh E.R. Muhammad. Bandung: Mizan.

Ghulsyani, Mahdi. 1998. Füsafat Sains menurut al-Qur'an. Terjemahan Agus Effendi. Bandung: Mizan.

Haught, John F. 2005. Pejumpaan Sains dan Agama: Dari Konflik ke Dialog. Terjemahan Fransiskus Borgias. Bandung: Mizan.

Jenie, Umar 'A. 2002. Ilmu Pengetahuan dan Teknologi dalam Perspektif Pemikiran Islam. Makalah disampaikan dalam Seminar Pengembangan IAIN Sunan Kalijaga. Reintegrasi Epistemologi Pengembangan Keilmuan di IAIN. Yogyakarta, 18-19 September.

Nasution, Harun. 1985. Islam Ditinjau dari Berbagai Aspeknya. Jakarta: UI Press.

Madjid, Nurcholish. 1992. Islam: Doktrin dan Peradaban. Jakarta: Yayasan Paramadina.

Rundell, Michael. 2002. (et.al). (Ed,). Macmillan English Dictionary, For Advanced Leraners: Internasional Student Edition. Oxford: Macmillan Publisher Limited. 2004. Menjembatani Sains dan Agama. Jakarta: Gunung Mulia. 